\title{
Determination of Response Modification Coefficient for Steel Chimneys by IDA and Pushover Analysis
}

\author{
A.Mehrazad TahamouliRodsari, B.Mohamad Amin Sharafiani, C.Ehsan Khosravi
}

\begin{abstract}
Industrial steel chimneys are in the group of the tallest shell shaped structures, and these structures are one of the most important parts of power plants. The main rule of chimneys is transferring Emissions resulting from fuels to the higher level of ground. In this article the capacity curve of the structure calculated by Incremental Dynamic Analysis (IDA) and nonlinear static analysis (pushover). Therefore, ductility, over strength, Deflection amplification factor and response modification coefficient were computed by considering capacity curve. For modeling of the chimney, finite element software ABAQUS is used. The results show good agreement between response modification coefficient obtained from IDA and poshover analysis with the coefficient that suggested by AISC code. Results show that response modification coefficient suggested by AISC code is conservative. At the second part two opening were added at the bottom of the chimney, and time history analyses for ten different earthquakes were applied on the chimney. Finally the value of Mises stresses compared for chimney with and without opening. The results show existence of opening increases significantly Mises stresses at the bottom of the chimney.
\end{abstract}

Index Terms-steel chimney, response modification coefficient, IDA and pushover analysis, opening

\section{Iintroduction}

Industrial steel chimneys are in the group of the tallest shell shaped structures, and these structures are one of the most important parts of power plants. The main rule of chimneys is transferring Emissions resulting from fuels to the higher level of ground. Researchers also pay attention to these structures especially in recent years that some of them have been mentioned.

Simonov et. Al. (2008) presented stress distribution as a cause of Steel Chimney Root Section Failure. This paper has studied failure initiation of the root section of $60 \mathrm{~m}$ tall industrial steel chimney [1]. Nikhil Asok $\mathrm{N}$ and Unnikrshnan (2008) presented design and optimization of a steel chimney. In this research a steel chimney designed with considering dead, wind and thermal loads. The Bureau of Indian Standards (BIS) design codes procedures used for the design of the steel

F. A. Assistant Professor, Department of Civil Engineering, Kermanshah Branch, Islamic Azad University, Kermanshah, Iran

S. B. M. Sc. In Civil Eng., Department of Civil Engineering, Kermanshah Branch, Islamic Azad University, Kermanshah, Iran

T. C. M. Sc. In Civil Eng., Department of Civil Engineering, Kermanshah Branch, Islamic Azad University, Kermanshah, Iran chimney. The steel chimney modeled in finite element software ANSYS [2]. Murali et. Al. (2012) discusses about response of mild Steel chimney Under Wind Loads. This paper deals with the study of three chimneys of $55 \mathrm{~m}$ high above ground level. These chimneys were designed as per IS: 6533-1989 and wind load was calculated as per IS: 875-1987 [3]. Sule and Nwofor (2012) presented the wind induced vibration of a Tall Steel Chimney. In this paper, the vortex induced vibration of a $50 \mathrm{~m}$ steel chimney under wind excitation is discussed. A steel chimney is modeled as a cantilever structure with consideration of two degrees of freedom, and Lumped parameter approach was employed to predict the frequencies of vibration of chimney [4]. Kirtikanta et. Al. (2013) explained about the Analysis of Self-supported Steel Chimney with the effects of manhole and geometrical properties. This study investigates the stresses, deflection and mode shapes of the chimney due to the presence of an inspection manhole. Maximum Von Mises stress, top deflection and mode shapes were calculated using finite element software ANSYS. The results show that presence of manhole increased the stresses approximately 1.5 times and frequency decreased approximately 1.12 times [5].

Response modification coefficient is an important factor to design structure against earthquakes. Powerful earthquakes cause steel chimneys into inelastic range, and nonlinear analysis is needed as an accurate analysis. Nonlinear analysis contains some complexity. Therefore, based on codes recommendations linear analysis with consideration of declined force of the earthquake could be acceptable. If behavior of structures during strong earthquakes assume elastic, applied forces will be huge. With entrance of structure into inelastic phase, the forces which are applied on the structure could be reduced and displacement could be increased. Response modification coefficient is factor that makes relationship between force of earthquake in elastic and inelastic behavior. One of the most important conditions for this transferring is providing ductility in the structures.

At the first part of the article nonlinear static analyses (pushover) were done on the structure, and then the capacity curve for chimney was calculated. With considering of capacity curve which was calculated in the last part, the response modification coefficient will be computed. At the second part of the article, twelve Earthquakes with different Peak Ground Acceleration (PGA) applied on the chimney, and nonlinear dynamic time history analysis will be used (with consideration simultaneous effect of the three component). The results show two of these earthquakes cause inelastic zone in the base of the chimneys. For these two earthquakes incremental dynamic nonlinear analysis were 
done on the structure. The capacity curve of the chimney could be one of the results of IDA analysis. Therefore, response modification coefficient will be calculated based on capacity curve. Finally, the results show good agreement between response modification coefficient obtained from IDA and pushover analysis with the coefficient that suggested by ASCE7 code [6]. The results show that response modification coefficient suggested by AISC code is conservative. At the third part two opening were added at the bottom of the chimney, and time history analyses for 10 different earthquakes were applied on the chimney. The value of Mises stresses compared for chimney with and without opening. The results show existence of opening increase significantly Mises stresses at the bottom of the chimney.

\section{The Geometry of Steel Chimney}

In this paper an industrial steel chimney with height of 60 meters was modeled. The geometry of steel chimney presented in Fig. 1. This structure is made up of five different parts. The thickness of the chimney decreases as the height increases. Thicknesses of these specimens are equals to $12,11,9,7$ and 5 mm.

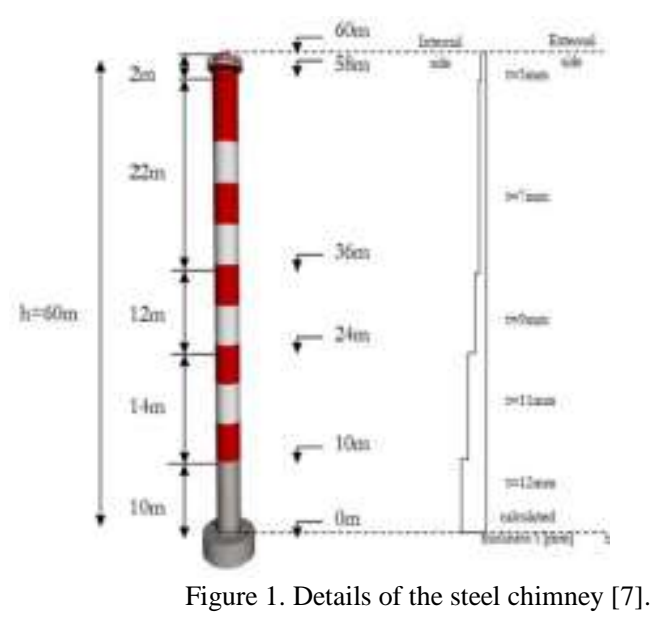

\section{Materials}

CORTEN S355 is the material that used for all models. In TABLE I mechanical properties of steel CORTEN S355 listed. This kind of steel is usual material that is used for industrial steel chimneys.

TABLE I: MECHANICAL PROPERTIES OF STEEL CORTEN S355 [7]

\begin{tabular}{|c|c|c|c||}
\hline $\begin{array}{c}\text { Mechanical } \\
\text { Properties }\end{array}$ & Symbol & Price & $\begin{array}{c}\text { Measurement } \\
\text { Units }\end{array}$ \\
\hline Elasticity Module & $\mathrm{E}$ & 199.00 & $\mathrm{GPA}$ \\
\hline Poisson Ratio & $v$ & 0.33 & - \\
\hline Density & $\rho$ & 7850.0 & $\mathrm{Kg} / \mathrm{m}^{3}$ \\
\hline Yield in capacity & $\mathrm{f}_{\mathrm{y}}$ & 355.00 & $\mathrm{MPa}$ \\
\hline Ultimate capacity & $\mathrm{f}_{\mathrm{u}}$ & 470 & $\mathrm{MPa}$ \\
\hline
\end{tabular}

\section{Numerical Modeling verification}

To verify the numerical modeling, the period obtained from both the equation proposed by ASCE7 and the finite element method software compared together. For achieving to this purpose, the steel chimney with constant thickness of $10 \mathrm{~mm}$ was selected. Geometric characteristic and material of steel chimney indicate in Fig. 2 and TABLE II, respectively. The equation 1 and 2 represent moment of inertia and period of structure.

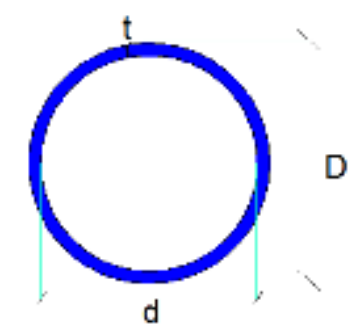

Figure 2. Geometry of section of steel chimney.

$$
\begin{aligned}
& \mathrm{I}=\pi \mathrm{r}^{4} / 4 \\
& \mathrm{~T}=0.018 \mathrm{~L} 2 \sqrt{ }(\mathrm{q} / \mathrm{g} \mathrm{E} \mathrm{I})
\end{aligned}
$$

TABLE II: FEATURES OF CHIMNEY

\begin{tabular}{|l|c|c|c|c|c|c|}
\hline $\begin{array}{l}(\mathbf{L}) \\
\mathbf{m}\end{array}$ & $\begin{array}{c}\mathbf{( D )} \\
\mathbf{m}\end{array}$ & $\begin{array}{c}\mathbf{( d )} \\
\mathbf{m}\end{array}$ & $\begin{array}{c}\mathbf{( t )} \\
\mathbf{m}\end{array}$ & $\begin{array}{c}\mathbf{( q )} \\
\mathbf{K g} / \mathbf{m}\end{array}$ & $\begin{array}{c}\mathbf{( E )} \\
\mathbf{K g} / \mathbf{c m}^{\mathbf{2}}\end{array}$ & $\begin{array}{c}(\mathbf{I}) \\
\mathbf{m}^{\mathbf{4}}\end{array}$ \\
\hline 50 & 2 & 1.98 & 0.01 & 490.76 & $2.1 \mathrm{E} 6$ & 0.03095 \\
\hline
\end{tabular}

\footnotetext{
L: height of the chimney

D: outer diameter

d: inner diameter

$\mathrm{t}$ : Thickness

q: Weight per unit length

E: modulus of elasticity

I: moment of inertia
}

TABLE III present differences between periods that were obtained from both the FEM software and the proposed equation by ASCE7. The results show a very small difference between the two methods and differences between two values are about $\% 1$.

TABLE III: DIFFERENCES BETWEEN PERIODS
\begin{tabular}{||c|c|c|c|}
\hline \hline $\begin{array}{c}\mathbf{L} \\
(\mathbf{m})\end{array}$ & $\begin{array}{c}\mathbf{T} \\
\text { ASCE(sec) }\end{array}$ & $\begin{array}{c}\text { T } \\
\text { FEM(sec) }\end{array}$ & ERROR\% \\
\hline 50 & 1.248 & 1.261 & 1 \\
\hline
\end{tabular}

\section{Nonlinear Static Analysis ( PUSHOVER)}

Nonlinear static analysis (pushover) has been used since 1970, and has been made remarkable progress in the last 20 years. Using this method is recommended by most reliable codes to evaluate the seismic performance of structures. In this method, after applying the gravity loads, lateral displacement was applied on the steel chimney with a specific pattern that it gradually increases. Pushover analysis is a simple method for evaluating the performance of structures that it leads to the capacity curve of structures, yield points and failure points of the structures.

At the first step, the steel chimney with the height of 60 meters was modeled by ABAQUS software, and modal 
analysis was applied on the structure. One of the most important results of modal analysis is frequency and mode shape of structure. The equation of the first mode shape was calculated by MATLAB software. This equation applied on the structure as a lateral displacement pattern, and then the chimney under this lateral load was analyzed by pushover method. Finally the capacity curve (base shear-displacement) of the chimney was plotted. Fig. 3 shows the capacity curve of the chimney that resulted from pushover analyses.

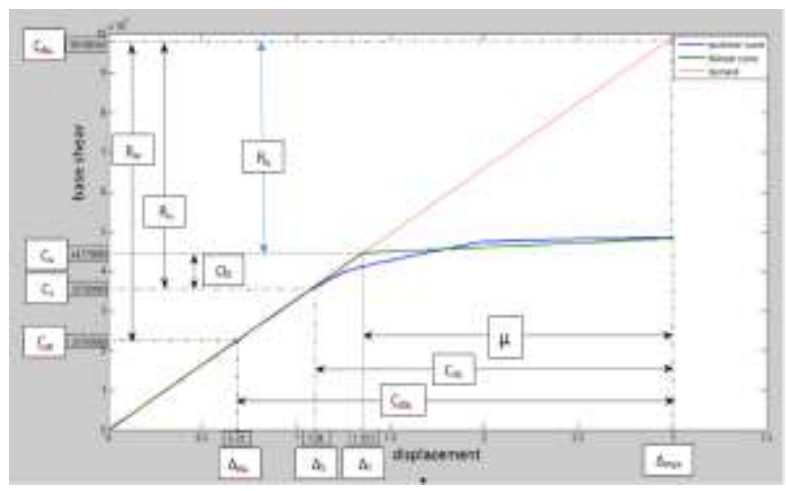

Figure 3 . The capacity curve of the chimney resulted from pushover analyses

\section{Definition of Effective Parameters in Response Modification Coefficient}

Response modification coefficient which is a reduction factor is used for transferring elastic force into inelastic force. One of the most important conditions for this transferring is providing ductility in the structure. There are some parameters that affect on the response modification coefficient. This parameters include a. ductility of the structure (division of maximum displacement by corresponding displacement at yielding point), b. over strength, c. redundancy factor (sequence of yielding point of the structures), and some others parameters.

a. ductility $\left(\mu_{\mathrm{S}}\right)$ : the capacity curve of the structure should be idealized to simplify the real curve of structures to bilinear curve. Fig. 3 illustrates bilinear curve for the chimney which is elasto-plastic [8]. Therefore ductility of structure will be defined based on below equation.

$$
\mu_{\mathrm{s}}=\Delta_{\max } / \Delta_{\mathrm{y}}
$$

In equation $3, \Delta_{\max }$ is maximum displacement and $\Delta_{\mathrm{y}}$ is Corresponding displacement at yielding point.

b. The corresponding ductility decrease factor $\left(R_{\mu}\right)$ : ductility causes energy dissipation for structures. Energy dissipation capacity changes elastic force of earthquake (demand force- $\mathrm{C}_{\mathrm{eu}}$ ) to yielding strength $\left(\mathrm{C}_{\mathrm{Y}}\right)$.

$$
\mathrm{R}_{\mu}=\mathrm{C}_{\mathrm{eu}} / \mathrm{C}_{\mathrm{Y}}
$$

In this part corresponding ductility decrease factor $\left(\mathrm{R}_{\mu}\right)$ calculated by Newmark-hall [9] equations that represent in equation 5 .

$$
\begin{cases}\mathrm{R}_{\mu}=1 & \mathrm{~T}<0.03 \mathrm{SEC} \\ \mathrm{R}_{\mu}=\sqrt{ }(2 \mu-1) & 0.12<\mathrm{T}<0.5 \mathrm{SEC} \\ \mathrm{R}_{\mu}=\mu & \mathrm{T}>1 \mathrm{SEC}\end{cases}
$$

c. Over strength coefficient $(\Omega)$ : this coefficient refers to sequential yielding of critical regions, material over strength (actual vs specified yield, strain hardening, capacity reduction factors and member selections). This coefficient equals to division of normalized level of yielding in structure by actual level of first yielding in structure.

$$
\Omega_{\mathrm{O}}=\mathrm{C}_{\mathrm{Y}} / \mathrm{C}_{\mathrm{S}}
$$

In equation $6, \mathrm{C}_{\mathrm{S}}$ is a parameter which refers to the first yielding point in the structure. $C_{S}$ is level of force that in this point real response of structure will be initiated to dramatic variance from elastic response. For calculating response modification coefficient, initial over strength must be multiply in some factors.

$$
\Omega=\left(\Omega_{\mathrm{O}}\right) * \mathrm{~F}_{1} * \mathrm{~F}_{2} * \mathrm{~F}_{3} * \ldots
$$

In equation $7, F_{i}$ refers to different factors, for example $F_{1}$ refers to the difference between nominal yielding limit and real yielding limit for materials. Statistical investigations show special value equals to 1.05 for steel structures. $F_{2}$ could be effect of raising in yielding stress. Statistical investigation determines this value as 1.1. And others parameters of $F$ refers to effect of nonstructural elements and others [10].

d. Coefficient of allowable stress (Y): For designing based on allowable stress design, the level of design force $\left(C_{\mathrm{s}}\right)$ will be decreased from the level of first significant yielding point $\left(\mathrm{C}_{\mathrm{w}}\right)$ by this factor.

$$
\mathrm{Y}=\mathrm{C}_{\mathrm{S}} / \mathrm{C}_{\mathrm{W}}
$$

In equation $8, \mathbf{C}_{\mathbf{W}}$ is the service design force. Allowable stress factor based on AISC-ASD could be calculated by equation 9. In this equation the value that equals to $4 / 3$ is extra value of allowable stress when earthquake loads are exist. Also the factor of $\mathrm{Z}$ is plastic modules of the section.

$$
\mathrm{Y}=\mathrm{C}_{\mathrm{S}} / \mathrm{C}_{\mathrm{W}}=\mathrm{M}_{\mathrm{P}} / \mathrm{M}_{\mathrm{W}}=\left(\mathrm{Z} * \mathrm{~F}_{\mathrm{y}}\right) /\left(\mathrm{S} *\left(0.6 \mathrm{~F}_{\mathrm{y}} * 4 / 3\right)\right)
$$

For tubular sections, the ratio of $\mathrm{Z} / \mathrm{S}$ is equal to 1.32 and the value of allowable stress factor is equal to 1.65. When the LRFD method will be selected, this factor (Y) will be equal to one [11].

e. determination of response modification coefficient $\left(\mathrm{R}_{\mathrm{u}}\right.$ and $\mathrm{R}_{\mathrm{w}}$ ): with consideration of Fig. 3, the response modification coefficient based on load and resistant factor design (LRFD) method will be calculated according to equation 10 .

$$
\mathrm{R}_{\mathrm{u}}=\mathrm{C}_{\mathrm{eu}} / \mathrm{C}_{\mathrm{S}}=\left(\mathrm{C}_{\mathrm{eu}} / \mathrm{C}_{\mathrm{y}}\right)\left(\mathrm{C}_{\mathrm{y}} / \mathrm{C}_{\mathrm{S}}\right)=\mathrm{R}_{\mu} \Omega
$$


The response modification coefficient based on allowable stress design (ASD) method will be calculated according to equation 11 .

$$
\mathrm{R}_{\mathrm{w}}=\mathrm{C}_{\mathrm{eu}} / \mathrm{C}_{\mathrm{w}}=\left(\mathrm{C}_{\mathrm{eu}} / \mathrm{C}_{\mathrm{y}}\right) *\left(\mathrm{C}_{\mathrm{y}} / \mathrm{C}_{\mathrm{S}}\right) *\left(\mathrm{C}_{\mathrm{S}} / \mathrm{C}_{\mathrm{w}}\right)=\mathrm{R}_{\mu} \Omega \mathrm{Y}
$$

\section{Calculation of response modification coefficient with consideration of the capacity curve obtained from pushover analysis}

The capacity curve for the chimney based on pushover analyses represent in Fig. 3. The only requirement for transferring real curve into bilinear curve is equal areas of two curves. The parameters which are related to response modification coefficient Obtained as follows:

$$
\begin{array}{ll}
\mathrm{C}_{\mathrm{eu}}=99188565 \mathrm{~N} & \Delta_{\max }=3.00 \mathrm{~m} \\
\mathrm{C}_{\mathrm{y}}=44779669 \mathrm{~N} & \Delta_{\mathrm{y}}=1.353 \mathrm{~m} \\
\mathrm{C}_{\mathrm{S}}=35700000 \mathrm{~N} & \Delta_{\mathrm{s}}=1.080 \mathrm{~m} \\
\mathrm{C}_{\mathrm{w}}=21636363 \mathrm{~N} & \Delta_{\mathrm{w}}=0.655 \mathrm{~m}
\end{array}
$$

With consideration of above values other parameters will be obtained:

$$
\begin{aligned}
& \mu \mathrm{s}=\Delta \max / \Delta \mathrm{y}=3 / 1.353=2.217 \\
& \mathrm{R} \mu=\mathrm{Ceu} / \mathrm{CY}=99188565 / 44779669=2.215 \\
& \Omega 0=\mathrm{CY} / \mathrm{CS}=44779669 / 35700000=1.254 \\
& \Omega=1.254 * 1.1 * 1.05=1.44837 \\
& \mathrm{Cds}=\Delta \max / \Delta \mathrm{s}=3 / 1.08=2.78 \\
& \mathrm{Cdw}=\Delta \max / \Delta \mathrm{w}=3 / 0.655=4.58 \\
& \mathrm{Y}=1.65 \\
& \mathrm{Ru}=\mathrm{Ceu} / \mathrm{CS}=(\mathrm{Ceu} / \mathrm{Cy})(\mathrm{Cy} / \mathrm{CS})=\mathrm{R} \mu \Omega= \\
& 2.215 * 1.44837=3.208 \\
& \mathrm{Rw}=\mathrm{Ceu} / \mathrm{Cw}==(\mathrm{Ceu} / \mathrm{Cy})(\mathrm{Cy} / \mathrm{CS})(\mathrm{CS} / \mathrm{Cw})=\mathrm{R} \mu \Omega \\
& \mathrm{Y}=3.208 * 1.65=5.29
\end{aligned}
$$

The results show that response modification coefficient obtained by pushover analysis equals to 5.29. The ASCE7 code recommends $\mathrm{R}$ equals to 5 for industrial steel chimney based on allowable stress design method. Therefore, there is a good agreement between responses in ASCE7 code and analyses. The results show that response modification coefficient recommended by ASCE7 code is conservative.

\section{Incremental nonlinear dynamic analysis}

Incremental nonlinear dynamics analyses include a great number of nonlinear dynamic time history analyses under different earthquake records. These records were scaled in a way that can cover linear and nonlinear range of behavior of structure. The main goal of this method is to calculate response of structure with various values of earthquake intensity. The results of this analysis are presented as IDA curves. In this part, Records of earthquakes are normalized in PGA and multiply in different coefficient of gravity acceleration $(0.1 \mathrm{~g}, 0.2 \mathrm{~g}, 0.3 \mathrm{~g} \ldots)$. Then, structures were analyzed under different values of PGA and the responses of structure (displacement and base shear) versus acceleration were plotted. In this study Incremental dynamic analysis (IDA) for CHICHI TAIWAN 1999 and NORTHRIDGE 1994 earthquakes were done (TABLE IV), and then for both earthquakes capacity curves were obtained. For example the records of Northridge earthquake are shown in Fig. 4. More than 50 analyses were carried out. Therefore, base shear versus displacement curve was plotted. Capacity curve obtained from Incremental nonlinear dynamics analyses for CHICHI TAIWAN 1999 and NORTHRIDGE 1994 earthquakes that represent respectively in Fig. 5 and 6 . TABLE V lists the values of response modification coefficient and some other parameters that related to $\mathrm{R}$. The results which are obtained by IDA and pushover analysis are close together. Response modification coefficient which is obtained by pushover analysis is a little lower than IDA analyses, and it shows that pushover analyses are conservative.

TABLE IV: CHARECTRESTIC OF EARTHQUAKES

\begin{tabular}{||c|c|c|c|c||}
\hline earthquakes & magnitude & $\begin{array}{c}\text { PGA } \\
\text { N_S }\end{array}$ & $\begin{array}{c}\text { PGA } \\
\text { E-W }\end{array}$ & $\begin{array}{c}\text { PGA } \\
\text { Vertical }\end{array}$ \\
\hline $\begin{array}{c}\text { CHICHI } \\
\text { TAIWAN } \\
1999\end{array}$ & 7.6 & 0.968 & 0.902 & 0.724 \\
\hline $\begin{array}{c}\text { NORTHRID } \\
\text { GE 1994 }\end{array}$ & 6.7 & 1.585 & 1.285 & 1.229 \\
\hline
\end{tabular}

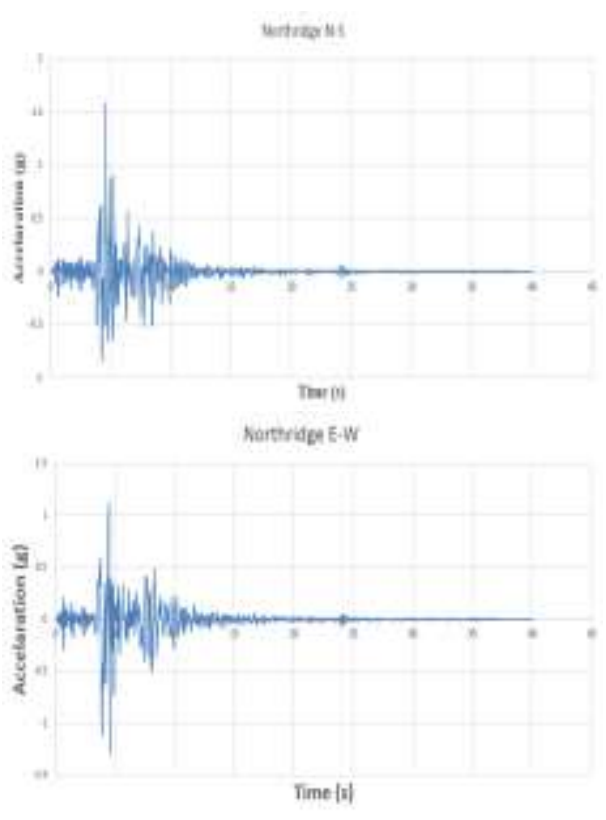


Proc. of The Fourth Intl. Conf. On Advances in Civil and Structural Engineering - CSE 2015

Copyright (C) Institute of Research Engineers and Doctors, USA .All rights reserved.

ISBN: 978-1-63248-070-5 doi: 10.15224/ 978-1-63248-070-5-49

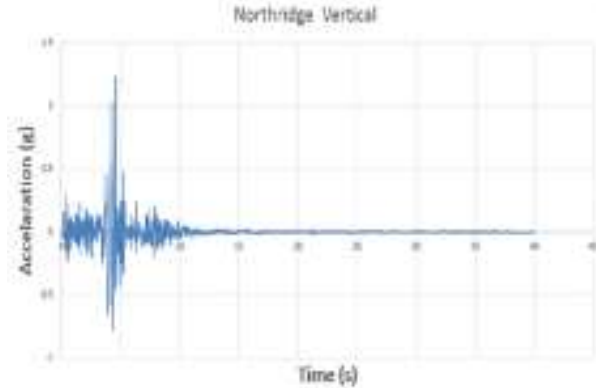

Figure 4. Records of northridge earthquake

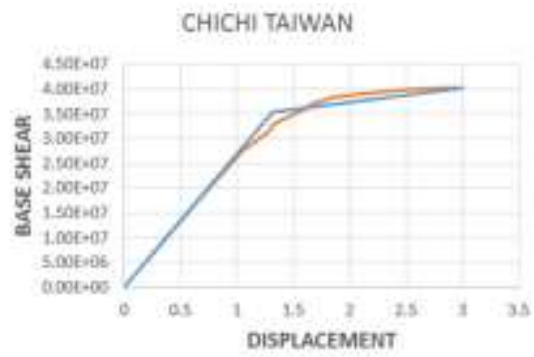

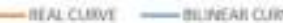

Figure 5. Capacity curve obtained from IDA (chichi)

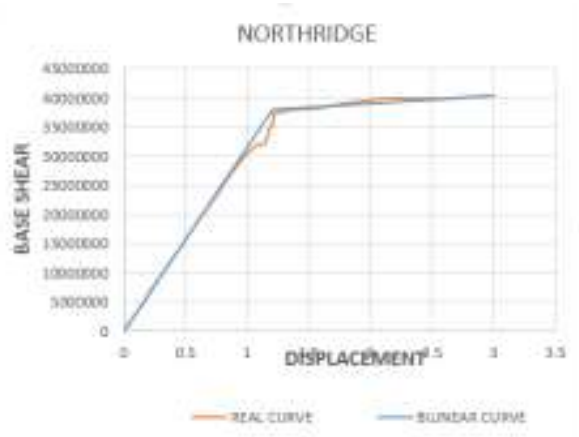

Figure 6. Capacity curve obtained from IDA (northridge)

TABLE V: VALUES OF R AND SOME OTHER PARAMETERS

\begin{tabular}{|c|c|c|c|}
\hline & $\begin{array}{c}\text { Ceu } \\
(\mathbf{K N})\end{array}$ & $\begin{array}{c}\text { Cy } \\
(\mathbf{K N})\end{array}$ & $\begin{array}{c}\text { Cs } \\
(\mathbf{K N})\end{array}$ \\
\hline PUSHOVER & 99188.5 & 44779.6 & 35700 \\
\hline IDA(CHICHI) & 80000 & 35342.8 & 23330 \\
\hline IDA(NORTHRIDGE & 94402.7 & 37949.9 & 28352.3 \\
\hline
\end{tabular}

\begin{tabular}{|c|c|c|c|c|}
\hline earthquakes & $\begin{array}{l}\text { magnihude } \\
\text { (rinthert) }\end{array}$ & $\begin{array}{l}\mathrm{PGA} \\
\mathrm{NSS}\end{array}$ & $\begin{array}{l}P G A \\
E, W\end{array}$ & $\begin{array}{l}\text { PGG } \\
\text { Vertical }\end{array}$ \\
\hline CHICHI TALWAN 1999 & 7.6 & 0.968 & 0.902 & 0.724 \\
\hline NORTHFIDGE IDS4 & 6.7 & 1.585 & 1.285 & 1.229 \\
\hline NAHANN CANADA L9SS & 6.9 & 2.056 & 1.095 & 0.978 \\
\hline SANFERNANDO IS1 & 6.6 & 1.236 & 1.16 & 0.695 \\
\hline GA2Z1 1076 & 20 & 1,267 & 2.605 & 0.718 \\
\hline MOMMOTHLAKKES I950 & - & 0.271 & 0.43 & 0.271 \\
\hline CAPE MENDOCYON 1992 & 7.4 & 1.487 & 1.095 & 0.754 \\
\hline IMPRELLAL VALIEY 1999 & 6.5 & 1.695 & 0.430 & 0.41 \\
\hline TADAS IRAN 1978 & 7.4 & 0.836 & 0.052 & 0.088 \\
\hline MORGANN HILI 195 & & 1.288 & 0.71 & 0.385 \\
\hline
\end{tabular}

TABLE VI: CHARACTERISTIC OF EARTHQUAKES

\begin{tabular}{|c|c|c|c||}
\hline & $\begin{array}{c}\Delta \mathbf{m a x} \\
(\mathbf{m})\end{array}$ & $\begin{array}{c}\Delta \mathbf{y} \\
(\mathbf{m})\end{array}$ & $\begin{array}{c}\Delta \mathbf{s} \\
(\mathbf{m})\end{array}$ \\
\hline PUSHOVER & 3 & 1.353 & 1.08 \\
\hline IDA(CHICHI) & 3 & 1.321 & 0.872 \\
\hline IDA(NORTHRIDGE) & 3 & 1.206 & 0.901 \\
\hline
\end{tabular}

\section{IX. effect of different earthquakes with consideration of opening on the chimney:}

Openings are used on the base of chimneys, and they are used for access and iterance of the gases. The seismic responses of chimneys change with consideration of opening because existence of openings reduced sectional moment of inertia and the stiffness of the structures. Existence of manhole causes significant effects on the seismic response of the structure, and these changes must be considered in design procedure of structure. In this part of paper two rectangular opening based on IS code [12] added at the base of the chimney. Fig. 7 show the geometry of opening which recommended by IS code.
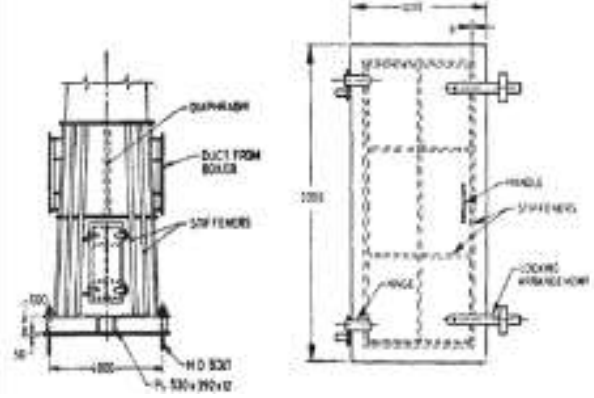

Figure 7. Details of manhole suggested by the IS code

10 different earthquakes were applied on the structure, and nonlinear time history analyses were done on the chimney. TABLE VI lists magnitude and PGA in three different directions of earthquakes. At the first part the chimney without consideration of opening was analyzed (for 10 different earthquakes), and values of Mises stresses were obtained for different part of chimney. Then the chimney with consideration of opening was analyzed, and different values of Mises stresses were investigated on the chimney. The structure affected by all three records of earthquakes simultaneously, and multi component analyses were done [13] The results show values of Mises stresses were increased significantly by existence of opening. Fig. 8 compares values of Mises stresses for chimney with and without manhole. 


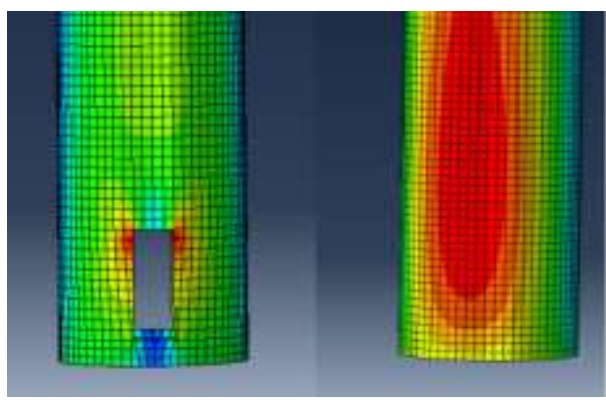

Figure 8. The comparison of the location of maximum stresses (Steel chimney with and without manhole).

Fig. 9 and 10 compare the maximum stresses and the average of stresses for 10 different earthquakes for the chimneys with and without opening. The results show existence of opening increase significantly Mises stresses at the bottom of the chimney. Existence of opening increases stress around the openings about 2 times. Theses maximum stresses located around the openings at the bottom of the chimney. The recent results show the effects of opening for design of these structures.

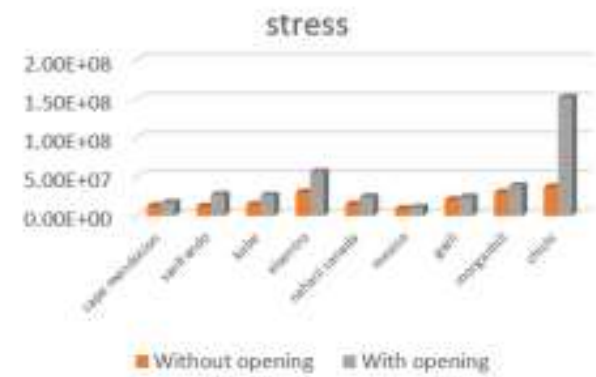

Figure 9. Stresses in chimneys with and without opening.

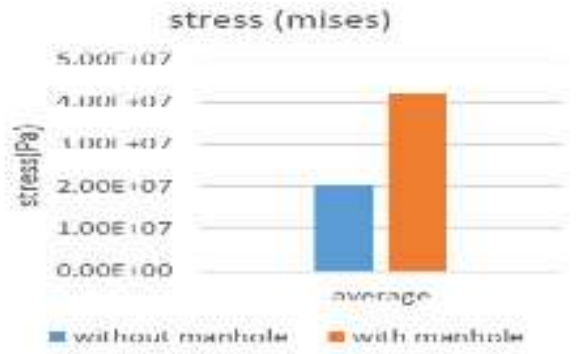

Figure 10. Average of stress.

\section{Conclusion}

With consideration of the represented results, TABLE V lists the values of response modification coefficient that obtained from allowable stress design method $\left(\mathrm{R}_{\mathrm{w}}\right)$ and Load and resistant factor design $\left(\mathrm{R}_{\mathrm{u}}\right)$. The response modification coefficient obtained by pushover analysis and ASD method equals to 5.29 that show good agreement with coefficient that suggested by ASCE7 code ( $\mathrm{R}_{\mathrm{W}}$ equals to 5). The results show that response modification coefficients in ASCE7 code are conservative. The response modification coefficients which obtained by incremental nonlinear dynamic analyses had bigger value rather than $\mathrm{R}$ that obtained by pushover analysis. Bigger values in response modification coefficient that obtained by IDA analysis reduced the base sheer force of earthquakes, and it leads to economical design. Over strength and ductility which calculated by IDA analyses are bigger than corresponding values computed by pushover analysis. IDA analyses predict a rather accurate response of structure against earthquake although these analyses are time consumer. Pushover predicts a conservative response modification coefficient for structure.

At the end of the paper two rectangular opening added at the bottom of the chimney, and time history analyses were done. Results show existence of opening increases significantly Mises stresses at the bottom of the chimney. Existence of opening increases stress around the openings about 2 times. These maximum stresses located around the openings at the bottom of the chimney.

\section{References}

[1] Simonović, Aleksandar M., Slobodan N. Stupar, and Ognjen M. Peković. "Stress distribution as a cause of industrial steel chimney root section failure." FME Transactions 36.3: 119-125, (2008).

[2] Nikhil Asok, N., and M. Unnikrshnan. "Design and optimization of a steel chimney." (2010).

[3] Murali, G., et al. "Response of Mild Steel chimney Under Wind Loads." International Journal of Engineering and Application, (2012).

[4] Sule, S, Nwofor T. C. "Wind Induced Vibration of a Tall Steel Chimney." Canadian Journal on Environmental, Construction and Civil Engineering: Vol. 3, No. 2, (2012).

[5] Sahoo, Kirtikanta, Pradip Sarkar, and Robin Davis. "Analysis of Self-supported Steel Chimney with the Effects of Manhole and Geometrical Properties."(2013).

[6] ASCE. "Minimum Design Loads for Buildings and Other Structures.' ASCE 7-98, Reston, Va, 1999.

[7] Gantes C. Associate Professor. "Behavior, Analysis and Design of Steel Chimneys." national technical university of athens department of civil engineering, (2011).

[8] Uyas, C.M., "estabilishing $\mathrm{R}$ or $\left(\mathrm{R}_{\mathrm{W}}\right)$ and $\mathrm{C}_{\mathrm{d}}$ factors for building seismic provision. ",Journal of structural engineering , ASCE , 1991, V.117,NO.1,pp.19-28,(1991).

[9] Newmark , N.M. , W.J.,"Prpcedures and Critiria for Earthquake resistant Design.” Building Practice for Disaster Mitigation, Nathional Bureau of Standards, (1973).

[10] Uyas, C.M., "Seismic Force Reduction and Displacement Amplification Factors." $10^{\text {th }}$ Word Conference on Earthquake Eng, Madrid, spain, 1992, 5875-5880, (1992).

[11] AISC, "Seismic provision for Structural steel Building ." ANSI/AISC 341-05, American Institute for Steel Construction, Chicago, Illinios ,(2010).

[12] IS 6533 Part 1; 1989, "Design and Construction of Steel Chimney", Bureau of Indian Standards, New Delhi,(2002).

[13] Roudsari, Mehrzad Tahamouli, and Mahmood Hosseini. "On the Relation between Rigorous and Simplified Models for the Dynamic Response Analysis of Multicomponent and Multisupport Excitations." Earthquake Spectra 29.2: 527-546, (2013 